Przegląd Badań Edukacyjnych Educational Studies Review

ISSN 1895-4308

nr 35 (2/2021), s. 197-212

Izabella Maria Łukasik

Maria Curie-Sklodowska University, Lublin, Poland

e-mail: luk3921@umcs.pl

ORCID: https://orcid.org/0000-0001-9983-8556
METAANALIZY

BADAN

EDUKACYJNYCH

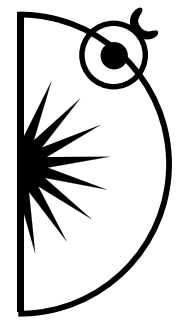

\title{
Student Well-Being in the Context of Erik Allardt's Theory of Welfare and Urie Bronfenbrenner's Ecological Systems Theory of Development
}

http://dx.doi.org/10.12775/PBE.2021.039

\begin{abstract}
:
Well-being can be described as the balance point between an individual's resources and difficult events in their life (Dodge et al., 2012). A student's well-being at school determines their educational success and functioning within their peer group in the school environment (Karataias et al., 2001; Huebner \& Gilman, 2002; Polard \& Lee, 2003; Engels et al., 2004; Konu \& Lintonen, 2005; Soutter et al., 2013; Renshaw et al., 2015; Opre et al., 2018). The purpose of this article is to identify indicators of student well-being in four categories: school conditions, interpersonal relationships, means of self-realization, and health referring to the School Well-Being Model by Konu and Rimpelā (Konu et al., 2002) (based on Allardt's concept) and situating them in Bronfenbrenner's socio-ecological system.

Having analyzed Erik Allardt's concept we decided to apply the dimensions of wellbeing he proposes to create measurable categories for recognizing levels of well-being. Allardt identifies three dimensions: having, loving, and being.

Students' assessment of the school situation in the context of individual preferences cannot be neglected, since well-being affects taking on challenges related to various educational tasks. Adequate recognition of difficulties makes it possible to intervene in areas that are most important to promoting well-being. The development and functioning of individuals depend on contexts which are described as the five systems in the ecological model: the microsystem, the mesosystem, the exosystem, the macrosystem, and the chronosystem.
\end{abstract}


The proposed well-being indicators can be used as items in questionnaire studies to obtain a multifaceted view of the conditions that influence students' sense of well-being. Recognizing the problem correctly allows the student to take corrective measures. The presented structure of student well-being indicators can be supplemented and expanded, to adapt to social, political, and health changes.

Keywords: student well-being, Erik Allardt's Theory of Welfare, Urie Bronfenbrenner's Ecological Systems Theory of Development.

\section{Introduction}

Student well-being is a widely studied construct in both psychology and education. Many definitions and models of well-being have emerged over the past forty years. Well-being can be viewed from two perspectives. The clinical perspective sees well-being as the absence of negative conditions such as depression, stress, anxiety, or substance abuse. The psychological perspective defines well-being as the preponderance of positive traits in an individual (Fraillon, 2004, pp. 15-18). Student well-being cannot be analyzed in isolation from the school context. It is useful to frame the school community itself, considering its members, participants in various activities, the existence of influences, and preferred values.

The popular-scientific standpoint defines well-being as the mental and physical feeling of one's actual situation. To a large extent, well-being depends on the extent to which our expectations are congruent or incongruent with what happens and how we assess the events (Nyczaj-Drąg, 2003, p. 71). According to Miroslawa Nyczaj-Drąg, students' well-being at school is a factor that determines the effectiveness of their actions to a large extent. The child's objective situation at school may differ significantly from their expectations. This gives rise to various negative emotions. Difficulties related to experiencing, desiring, and expecting, and then facing the outcome are addressed by concepts of cognitive psychology. Nadine Engels et al. see the issue in a similar light (2004, p. 128). They define student well-being as "a positive emotional state resulting from the harmony between the sum of specific contextual factors on the one hand and personal needs and expectations of the school on the other hand." The most important thing is to be in a positive emotional state, not to recognize the absence of illness or stress. On the other hand, students need to align their needs and expectations with the specific conditions and demands of the school (Kristof, 1996, p. 1). 
A review of the literature highlights the problematic nature of clearly defining the concept (Ryff \& Keyes, 1995; Konu \& Rimpelā, 2002; Ben-Arieh \& Frønes, 2011; Dodge et al., 2012).

Well-being refers to students' psychological, cognitive, social, and physical functioning and the abilities they need for a happy and fulfilling life. It is important to acknowledge the multifaceted nature of the concepts of well-being, which include both subjective experiences and objective circumstances. Wellbeing is the answer to the question of how a person feels given the social and physical conditions. Definitions of well-being do not have a single designator but they share the presence of positive emotions and the absence of indications of mental health disorders (The Australian Institute of Health and Welfare AIHW, 2012, after Cocoradă \& Orzea, 2017, p. 191). In his holistic pedagogy on the school situation, Andrew Szyszko-Bohusz, exposes the role of emotions in education (1989).

A new definition of well-being has been proposed where it is defined as a point of balance between personal resources and the challenges one faces. Well-being can be stable when individuals have the psychological, social, and physical resources they need to meet a particular psychological, social, and/or physical challenge. Environmental, school, and work factors cannot be underestimated (Diener et al., 2006). Consequently, students' well-being is difficult to predict due to the extraordinary complexity of perceptions, feelings, and the human condition. Students' well-being at school refers not only to their psychological well-being, but also to perceptions of physical well-being, as well as to social relationships, and material conditions. It is related to the realization of needs, where one can probably refer to Maslow's hierarchy of needs. It depends on the recognized resources that in some way can be useful in satisfying one's needs and expectations. Well-being also reflects the fulfillment of life plans, aspirations, and desires. One of the more recent attempts to define well-being suggests it is a balance between sources of resources and moving towards making changes. Well-being has many different constructs depending on the domain that conceptualizes it.

"The term school well-being can be considered a student's subjectively perceived sense of happiness, success, and self-satisfaction through the lens of school achieved success" (Kizeweter, 2016, p. 29). Assessments of student well-being in the school context include measurable indicators such as grades, test scores, attendance, and visits to the counselor, school psychologist, or principal. After introducing the Global School Health Initiative (WHO, 1998), more attention has been paid to conceptualizing student well-being in education. Stu- 
dent well-being refers to constructs such as physical and mental health, risk reduction, resilience, and climate and environmental conditions that are conducive to attending schools, such as safety, challenge, support, relationships, and engagement. School climate is also of great importance.

The WHO defines positive mental health as "a state of well-being in which the individual is aware of their abilities, can cope with the normal life stress, can work productively and effectively, and can contribute to their community" (WHO, 2001, after Huppert, 2009, p. 138).

The literature offers research reports on children's well-being at school such as those by Karataias et al. (2001), Huebner \& Gilman (2002), Polard \& Lee (2003); Engels et al. (2004), Konu \& Lintonen (2005), Soutter et al. (2013), Renshaw et al. (2015) and Opre et al. (2018).

Having analyzed Erik Allardt's concept we decided to apply the dimensions of well-being proposed by him to create measurable categories for recognizing levels of well-being. The purpose of this article is to identify indicators of student well-being in four categories: school conditions, interpersonal relationships, means of self-realization, and health, referring to the School WellBeing Model by Konu and Rimpelā, 2002 (based on Allardt's concept) and situating them in Bronfenbrenner's socio-ecological system.

\section{The importance of student well-being for social functioning and life challenges}

Determining a student's well-being at school is important in terms of their social functioning, school achievement, and future plans. Research shows that people with high levels of well-being are cooperative, confident, and creative, and they exhibit tolerant and altruistic attitudes (Lyubomirsky et al., 2005; Cohen \& Pressman, 2006). They can also cope with difficult situations better (Fredrickson et al., 2003). Well-being at school means fewer risk behaviors, as well as better physical health in adulthood (Caprara et al., 2000). Student well-being is a good predictor of academic performance (Renshaw \& Arslan, 2016). Student well-being at school should be considered as a subjective perception of events in various everyday situations that can somehow be described more objectively. The emotional dimension of well-being translates into mental, physical, social, and spiritual health. Positive emotions can shape beliefs, build physical well-being, and influence perceptions of health (Salovey et al., 2000). Pleasant sensations are not indifferent to health. First, the effects of positive emotions are observed on physiology, especially on the immune system. Depressed in- 
dividuals report more frequent somatic complaints than non-depressed individuals (Irvin, 1999; Banas et al., 2005; Rzeszutek \& Schier, 2008), and are less positive about their health. Positive emotional experiences build psychological resources that can be used to cope effectively and even prevent health problems. Negative emotional experiences were found to be associated with smoking, among others (Brandon, 1994). Pressman and Cohen (2006, in Huppert, 2009, p. 150) concluded, after experimental studies, that there is strong evidence for beneficial effects of positive emotions on physical health and that these effects may be independent of the level of experienced negative emotions. Lisa Feldman Barrett (2020) presented a theory of constructed emotion that contradicts the veracity of the claims of the traditional understanding of emotions. She interprets the expression of emotions by the body in a completely different way, and she does not see "special signs" but individualized experiences, characterized by neurobiology, connected with cognition and culture. A new approach to the construction of well-being was introduced by Randolph M. Nesse (2020), who reached for arguments from the discoveries of evolutionary psychiatry. It is important to recognize that students' well-being is an important factor for their success in education. Ferdinand Eder (1995, in Van Petegem et al., 2007, p. 448) draws attention to two aspects of perceived student well-being. On the one hand, it is the current indicator of the perception of oneself in a specific situation, i.e. the experience of emotions, psychosomatic sensations caused by a given school situation, the feeling of satisfaction. On the other hand, there is general self-esteem, insight into one's abilities, and the presented self-image.

\section{Dimensions of well-being in literature}

Anna Gawel (2009, p. 101) suggested that the school psychosocial environment can be understood as students' perceptions of the school climate. She identified and examined three dimensions: educational, social, and emotional. Each of the dimensions of the school's psychosocial environment was described by appropriate indicators. The educational dimension was determined by the perception of school requirements, perception of learning progress control practices, and the assessment of the learning burden. Regarding the social dimension, the following were found to be relevant: assessment of support from teachers, assessment of support from other students, and a sense of influence on the school life. Indicators of the emotional dimension included a sense of identification with one's school and a sense of belonging to one's class. 
Elizabeth L. Pollard and Patrice D. Lee (2003) identified five domains of child well-being: physical, economic, psychological, cognitive, and social, based on a systematic review of the literature in five English language databases on child well-being. Their review was a continuation of research from 1974-1992. They found that the definitions were inconsistent. Well-being was generally measured in a single domain with an emphasis on deficits rather than strengths. The authors noted the need to develop a set of positive indicators of child well-being in each domain.

The interpersonal dimension of the operational model of student well-being should be defined as the student's internalized sense of self and, consequently, their ability to function in the school community. The intrapersonal dimension of the operational model for measuring student well-being should consist of nine aspects: autonomy, emotional regulation, resilience, self-efficacy, self-esteem, spirituality, curiosity, engagement, and mastery orientation (Fraillon, 2004, p. 37), which can be thought of as a set of implicit beliefs that intelligence and abilities can be developed through a commitment to action, persistence and, in fact, hard work.

It has been proposed that the interpersonal dimension of the operational model for measuring student well-being be defined as a student's assessment of their social situation and the resulting ability to function in the school community. The interpersonal dimension alone of the operational model for measuring student well-being should include four aspects: effectiveness of communication, empathy, acceptance, and relationships (Fraillon, 2004, p. 37).

In recent years, interest in the topic of well-being has resulted in the development of research tools in which various dimensions and measurement indicators are proposed. Such examples of tests and their dimensions include: The Quality of School Life QSL Epstein, Mcpartland (1976) (general satisfaction with school, involvement in school activities, attitudes toward teachers); The Quality of Student Questionnaire QSLO (Keith \& Shalock, 1994) (satisfaction, well-being, social belonging, reinforcement/control); Quality of School Life (Karatzias et al., 2001) (student opinion about the quality of school life, satisfaction with the school); The Multidimensional Students' Life Satisfaction Scale MSLSS (Huebner \& Gilman, 2002) (satisfaction with: school, self, family, friends, living environment); School Well-being Profile (Konu \& Lintonen, 2005) (school and physical conditions: ventilation, toilets, facilities, temperature; time pressure; relationships with teachers; teacher interest in student progress; fair treatment; health); The Personal Wellbeing Index-School Children PWI-SC (Tomyn \& Cummins, 2005; 2011) (standard of living, personal health, life achievements, personal relationships, personal safety, feeling part of the 
community, future safety); The Student Well-being Model SWBM (Soutter et al., 2013) (having, being, relationships, feelings, thinking, functioning, aspirations); The Student Subjective Wellbeing Questionnare ISWQ (Renshaw et al., 2015) (feeling connected/bonds with the school, academic efficacy, enjoying learning, educational goals); The Adolescence School Subjective Well-being Scale ASSWBS (Opre et al., 2018) (identification with the school; learning and personal growth; safety; relationships with peers; relationships with teachers; emotional well-being; family relationships).

Because well-being affects many spheres of human functioning, it is important to recognize its level, especially in school situations. Identifying the critical points will help take educational measures. For example, the School Well-being Profile used in the Kulumiete project in Finland with 1346 pupils in 69 classes from 7th to 9th grade showed the need to improve school conditions in terms of ventilation, temperature control, and toilet cleanliness. Time pressure was also a concern for the pupils. Students' relations with teachers, teachers' interest in students' progress, and teachers' fair treatment of students became topics for debate. Students complained of headaches, feeling tired, and weak. This knowledge can be properly used for planning interventions and promoting well-being and mental health at school.

\section{Categories and indicators of student well-being in the context of The Ecological Systems Theory}

We used Erik Allardt's concept to extract the dimensions of student well-being using the most important indicators of subjective well-being. Allardt's concept is sociological and considers the concept of well-being and happiness. Well-being has an objective dimension, resulting from the satisfaction of needs. Happiness, on the other hand, is a subjective feeling. People function in different areas of life, and Allardt emphasizes the importance of three dimensions:

- Having - these are the material conditions of life; to satisfy their physical needs and the need for safety, the individual must mobilize their sources of possession. Here, according to Allardt, one can point to economic resources (income), employment and working conditions, nutrition, health, etc. Education, especially literacy, would probably fit here as well (Allardt, 1973).

- Loving - refers to social life, social relationships (family, friends...), and to the need to establish relationships with other people, the formation of social identities (the level of contacts in the local community), 
attachment to family and relatives, active patterns of friendship, attachment and contacts with other members of the organization, relationships with colleagues, and solidarity are important (Allarat, 2003, p. 4).

- Being - should be associated with psychological well-being, satisfaction with self, environment, society, self-realization, and self-esteem (Petelewicz, 2016, p. 28). Being is the need to integrate into society and live in harmony with nature. The positive side of being is personal development, the negative side is alienation. Indicators include participation in decisions and activities that affect life, political activities, opportunities for leisure time, opportunities for meaningful work life, opportunities to enjoy nature through contemplation or activities such as walking, gardening, and fishing (Allarat, 2003, p. 5). Being as a value is related to many other concepts such as personal growth, satisfying developmental needs, and self-realization. It refers to the dimension with alienation on the one hand and self-realization on the other. Interestingly, elimination of "poor social conditions" results in a decrease in dissatisfaction, but does not increase, a person's satisfaction (Allardt, 1973).

Well-being is related to teaching, education, learning, and achievements, thus it is a key concept of school well-being (Konu \& Rimpelā, 2002, p. 79). Using Allardt's concept, Konu and Rimpelā (2002) grouped student well-being indicators into four categories:

1. School conditions,

2. Interpersonal relationships,

3. Means of self-realization,

4. Health.

Each category focuses on an underlying problem, e.g., means of self-realization refer to students' ability to learn using their resources and abilities. Health is visible in illnesses and their symptoms. The influence of the family is important. Allardt uses the word "well-being" which in Scandinavian languages also means good mood and includes aspects of both standards of living and quality of life (Allardt, 1989, p. 7). According to Allardt, well-being is a state in which an individual can satisfy their basic needs (tangible and intangible). Well-being is based on health, which Allardt places in the category of having.

The model of student well-being dependent on environmental contexts requires providing more details. Examples of its dimensions were provided referring to Allardt (2003) and a case study of a New Zealand secondary school cited by Soutter et al. (2013) involving a critical analysis of education policy in New Zealand and a qualitative study with New Zealand students (The Student WellBeing Model, SWBM). 


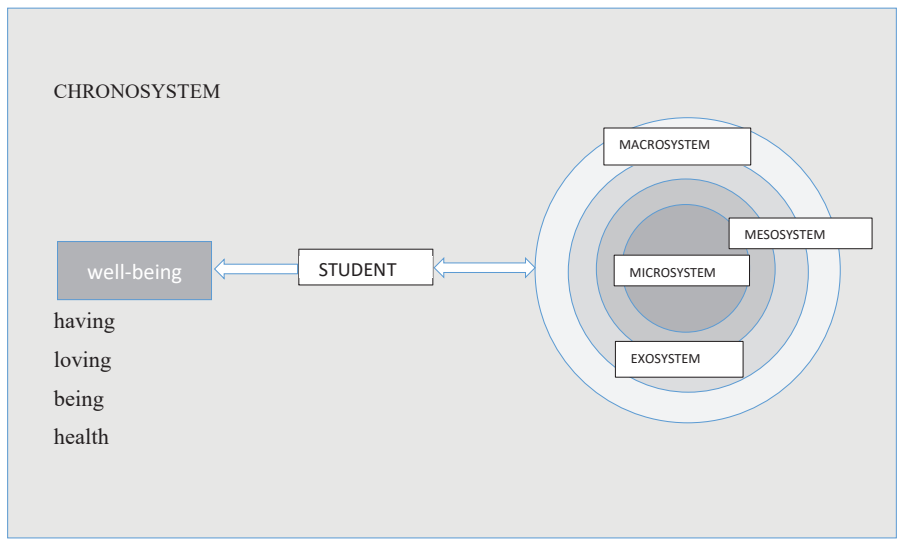

Figure 1. A model of student well-being at school and its environmental determinants

Source: Author's model.

Most important for well-being are the two-way interactions between the student and the components of various systems. Modifying his ecological theory, Bronfenbrenner drew attention to the importance of proximal processes. He recognized them as major mechanisms of individual development. A person enters into specific roles. The role of a student has a specific character. It is associated not only with education, but also with social functioning with peers, social relations, and involvement in school activities. Individuals are endowed with unique characteristics that are important for their development and social interactions.

Among personal characteristics, the most important are gender, age, physical and mental health, personality, temperament, and intelligence. The development and functioning of individuals depend on contexts described as five systems in the ecological model: the microsystem, the mesosystem, the exosystem, the macrosystem, and the chronosystem. Time is the key factor. Personal development is dynamic progress that can be measured using appropriate scales. Time is not indifferent, it affects systemic interactions during the life of an individual, and it even leaves its mark on generations: family values, beliefs, and ethical principles passed from generation to generation affect individuals in real time.

The microsystem is the child's immediate environment with strong bidirectional influences. The school, in all its complexity, is part of this system alongside family, peers, church, and health services. Three dimensions proposed by Allardt are present here: having (primarily understood as working conditions at school), loving (social relationships), and being (means of self-realization at school). 
Table 1. Indicators of student well-being in the microsystem

\begin{tabular}{|c|c|c|c|}
\hline \multicolumn{4}{|c|}{ MICROSYSTEM } \\
\hline $\begin{array}{l}\text { safe learning environment, } \\
\text { coziness, no noise, good air con- } \\
\text { ditioning, ventilation, adequate } \\
\text { temperature } \\
\text { ergonomic principles are followed: } \\
\text { properly sized tables and chairs, } \\
\text { properly prepared computer } \\
\text { workstations } \\
\text { cleanliness and hygiene at the } \\
\text { premises: classrooms, bathrooms, } \\
\text { corridors, common areas } \\
\text { space for relaxation: possibility of } \\
\text { playing outdoors, a place with the } \\
\text { possibility of having a nap } \\
\text { appropriate space for consuming } \\
\text { meals } \\
\text { appropriate learning environment: } \\
\text { curriculum, group size, timetables, } \\
\text { order and tidiness } \\
\text { material resources acquired } \\
\text { through personal effort, gifts, } \\
\text { exchanges, access to affordable } \\
\text { software or services } \\
\text { cultural needs } \\
\text { funds for the school operation are } \\
\text { sufficient to meet instructional ne- } \\
\text { eds and provide broader learning } \\
\text { athletic, cultural, spiritual, and } \\
\text { artistic activities } \\
\text { pastoral care, health care, } \\
\text { recreation, leisure, participation in } \\
\text { cultural events } \\
\text { sted to students' developmental, } \\
\text { ensuring all students work with } \\
\text { highly qualified teachers who set } \\
\text { aside adequate time for recre- } \\
\text { ation, have the funds to continue } \\
\text { their training, have a sense of } \\
\text { purpose, and an appropriate level } \\
\text { of enthusiasm } \\
\text { quality information resources } \\
\text { are available for students and } \\
\text { teachers. } \\
\end{array}$ & 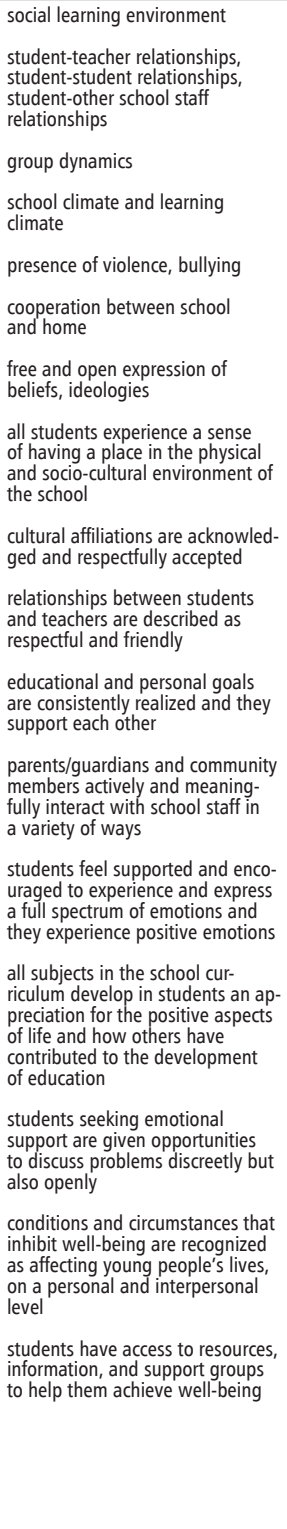 & 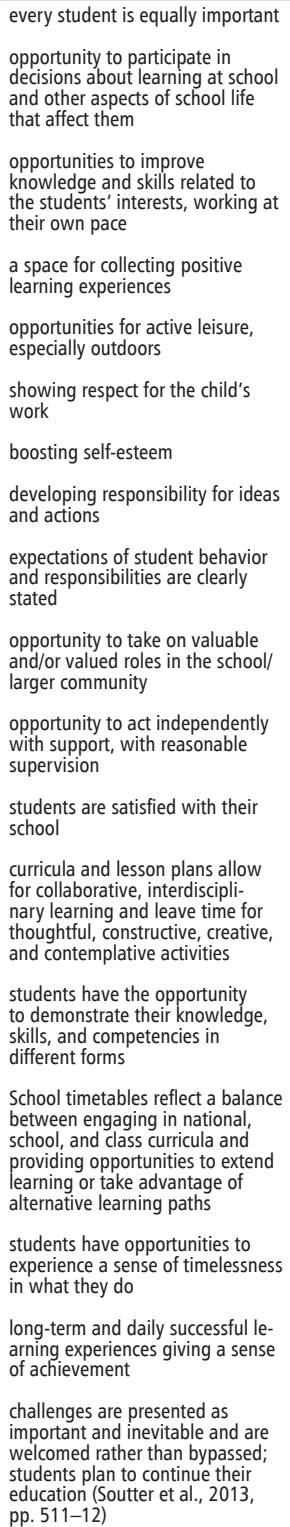 & $\begin{array}{l}\text { physical } \\
\text { mental } \\
\text { social } \\
\text { spiritual } \\
\text { students are well-nourished and } \\
\text { rested } \\
\text { psychosomatic symptoms are } \\
\text { observed } \\
\text { chronic illnesses, strains, other } \\
\text { ailments }\end{array}$ \\
\hline
\end{tabular}

Source: Author's compilation. 
The mesosystem connects two or more systems. Indicators were not exposed within the four recognized categories because of the vast number of dimensions that build relationships between the systems. The mesosystem builds connections between different elements of the microstructure, for example, the relationship between a student's teacher and parent translates into the functioning of the student. The child can get the necessary support and material or psychological help. Relationships between teachers and institutions can help students acquire broader competencies and result in the school's richer educational offer. Daily, students engage in learning experiences that transcend disciplinary, generational, cultural, and ideological boundaries, and require them to go beyond immediate and familiar contexts.

There are various types of social services within the exosystem. The neighborhood, local politics, and mass media play an important role here. Although students do not function in these structures directly, some factors influence their development through numerous interactions with certain structures in the microsystem.

Table 2. Indicators of student well-being in the exosystem

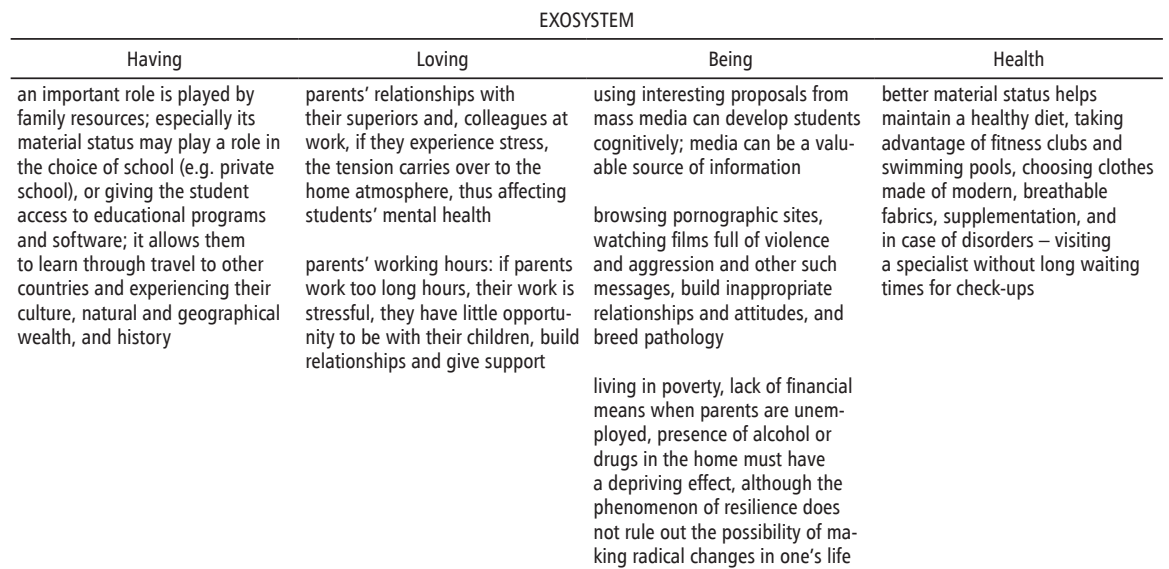

Source: Author's compilation.

The macrosystem considers the broad cultural context, the operating rules the student abides by but is often unable to control. 
Table 3. Indicators of student well-being in the macrosystem

\begin{tabular}{|c|c|c|c|}
\hline Having & Loving & Being & Health \\
\hline $\begin{array}{l}\text { the social system and established } \\
\text { social hierarchies build social } \\
\text { justice, wealth distribution, and } \\
\text { educational opportunities } \\
\text { students from poor backgrounds } \\
\text { can learn thanks to appropriate } \\
\text { government policies that support } \\
\text { young people in their educational } \\
\text { endeavors }\end{array}$ & $\begin{array}{l}\text { faith, belonging to a certain } \\
\text { religious tradition is the basis } \\
\text { for creating attitudes, including } \\
\text { those that discriminate against } \\
\text { otherness or the ones that shape } \\
\text { tolerance; this affects later life, } \\
\text { building relationships, raising } \\
\text { children, opportunities to develop } \\
\text { depending on, for example, } \\
\text { gender }\end{array}$ & $\begin{array}{l}\text { migration, lack of permanent } \\
\text { residence, a citizen of the world } \\
\text { without cultural roots, may } \\
\text { become a person without identity, } \\
\text { or alienated } \\
\text { if parents migrate from place to } \\
\text { place due to their work, the child } \\
\text { loses friends, cannot build lasting } \\
\text { relationships, loses a sense of } \\
\text { security, etc. }\end{array}$ & $\begin{array}{l}\text { people may follow various health } \\
\text { practices and customs that affect } \\
\text { the children's health in different } \\
\text { ways e.g. girl circumcision or } \\
\text { unhygienically made tattoos }\end{array}$ \\
\hline
\end{tabular}

Source: Author's compilation.

The chronosystem focuses on the interactions between different systems and how they impact one another in time. Even single events can have farreaching repercussions. An example is telling a child off for disobedience. The situation takes place in a microsystem, but it reinforces the cultural belief that the child must obey their parents. In adulthood, the child may become more submissive to dominant people. Bronfenbrenner's later work refers to the PPCT Process-Person-Context-Time model, where the child's well-being is also influenced by socio-historical circumstances. The chronosystem allows the child to use all their experiences.

\section{Conclusion}

Research on the impact of well-being on human functioning in various areas of life, including the one cited in the present article, confirms the relevance of identifying indicators of student well-being and highlighting the variety of its environmental determinants.

The complexity of the personal characteristics of individuals, the multiplicity of contexts, and environmental conditions do not allow us to assign students to groups with identified well-being. However, it is possible to extract indicators that can be organized into scales, and create tools to measure the intensity of a trait, that will allow researchers to compare students in terms of perceived well-being. Research using such tools provides insight into students' school situation, and difficulties detected during the process can be used to take specialized corrective measures. Such a tool was developed in the Department of Pedeutology and Health Education at the Institute of Pedagogy, at Maria Curie-Skłodowska University, in Lublin, Poland. ${ }^{1}$

${ }^{1}$ A. Buczak, \& I.M., Łukasik, Student's Well-Being in e-School. Description of the Tool 
Students' well-being and, above all, its determinants can be identified during community interviews considering the selected scopes of the analyzed problem. This in turn can be used to counteract or reduce the difficulties that prevent students from achieving school success.

The presented structure of indicators of student well-being can be supplemented and expanded, especially to address social, political, and health changes.

\section{References}

Allardt, E. (1973). A Welfare Model for Selecting Indicators of National Development. Policy Sciences, 4, 63-74, doi: 10.1007/BF01404933.

Allardt, E. (1989). Recent Developments in Scandinavian Sociology. Annual Review of Sociology, 15, 31-45, doi: 10.1146/annurev.so.15.080189.000335.

Allardt, E. (2003). Having, Loving, Being: An Alternative to the Swedish Model of Welfare Research. In: M. Nussbaum, \& A. Sen. The Quality of Life. Retrieved 20 August 2021 from: https://oxford.universitypressscholarship.com/view/10.1093/0198287976.001.0 001/acprof-9780198287971-chapter-8?print=pdf.

Banaś, A., Wichowicz, H., Gałuszko, M., \& Jakuszkowiak, K (2005). Współchorobowość somatyczna w zaburzeniach depresyjnych [Somatic Comorbidity in Depressive Disorders]. Psychiatria w Praktyce Ogólnolekarskiej, 2(5), 69-73.

Barrett, F.L. (2020). Jak powstają emocje. Sekretne życie mózgu [How Emotions Are Made. The Secret Life of the Brain]. Warszawa: Wydawnictwo CeDeWu.

Ben-Arieh, A., \& Frønes, I. (2011). Taxonomy for Child Well-Being Indicators: A Framework for the Analysis of the Well-Being of Children. Childhood, (4), 460-476, doi: $10.1177 / 0907568211398159$.

Brandon, T.H. (1994). Negative Affect as Motivation to Smoke. Current Directions in Psychological Science, 3, 33-37, doi: 10.1111\%2F1467-8721.ep10769919.

Caprara, G.V., Barbaranelli, C., Pastorelli, C., Bandura, A., \& Zimbardo, P.H. (2000). Prosocial Foundations of Children's Academic Achievement. American Psychological Society, 11(4), 302-306, doi: 10.1111/1467-9280.00260.

Cocoradă, E., \& Orzea, I.E. (2017). Relationships Between Wellbeing, Resilience and School Climate. Bulletin of the Transilvania University of Braşov - Special Issue Series VII: Social Sciences $\bullet$ Law •10(59), 2, 191-200, doi: 10.1016/j.ijer.2018.01.012.

Design and Test Results. The article has been accepted for publication in the International Journal of Research in E-learning (part of a team project implemented at the Department under my guidance entitled "Student well-being at e-school", as a module of the project "School well-being of students and teachers in the context of future tasks"). 
Cohen, S., \& Pressman, S.D. (2006). Positive Affect and Health. Current Directions in Psychological Science, 15(3), 122-125, doi: 10.1111/j.0963-7214.2006.00420.x.

Diener, E., Lucas, R.E., \& Scollon, C.N. (2006). Beyond the Hedonic Treadmill: Revising the Adaptation Theory of Well-Being. American Psychologist, 61(4), 305-314, doi: 10.1037/0003-066X.61.4.305.

Dodge, R., Daly, A.P., Huyton, J., \& Sanders, L.D. (2012). The Challenge of Defining Wellbeing. International Journal of Wellbeing, 2(3), 222-235, doi: 10.5502/ijw.v2i3.4.

Engels, N., Aelterman, A., Schepens, A., \& Van Petegem, K. (2004). Factors which Influence the Well-Being of Pupils in Flemish Secondary Schools. Educational Studies, 30, 127 143, doi: 10/1080.0305569032000159787.

Epstein, J.L., \& Mcpartland, J.M. (1976). The Concept and Measurement of the Quality of School Life. The American Educational Research Journal (AERJ), 13(1), 15-30, doi: $10.3102 / 00028312013001015$.

Fraillon, J. (The Australian Council for Educational Research) (2004). Measuring Student Well-Being in the Context of Australian Schooling: Discussion Paper Commissioned by the South Australian Department of Education and Children's Services as an Agent of the Ministerial Council on Education, Employment, Training and Youth Affairs (MCEETYA). Retrieved 20 August 2021 from: http://works.bepress.com/julian_fraillon/60/.

Fredrickson, B.L., Tugade, M.M., Waugh, Ch.E., \& Larkin, G.R. (2003). What Good Are Positive Emotions in Crises? A Prospective Study of Resilience and Emotions Following the Terrorist Attacks on the United States on September 11 ${ }^{\text {th }}, 2001$. The Journal of Personality and Social Psychology, 84(2), 365-376, doi: 10.1037/0022-3514.84.2.365.

Gaweł, A. (2009). Środowisko psychospołeczne szkoły a zdrowie uczniów [Psychosocial Environment of School and Students' Health]. Kultura i Edukacja, 1(70), 92-110.

Huebner, E.S., \& Gilman, R. (2002). An Introduction to the Multidimensional Students' Life Satisfaction Scale. Social Indicators Research, 60, 115-122, doi: 10.1023/A:1021252812882.

Huppert, F.A. (2009). Psychological Well-Being: Evidence Regarding its Causes and Consequences. Applied Psychology: Health and Well-being, 1(2), 137-164, doi: 10.1111/j.1758-0854.2009.01008.x.

Irvin, M. (1999). Immune Correlates of Depression. Advances in Experimental Medicine and Biology, 461, 1-24, doi: 10.1007/978-0-585-37970-8_10854.2009.01008.x.

Karatzias, A., Power, K.G., \& Swanson, V. (2001). Quality of School Life: Development and Preliminary Standardisation of an Instrument Based on Performance Indicators in Scottish Secondary Schools. School Effectiveness and School Improvement, 12(3), 265-284, doi: 10.1076/sesi.12.3.265.3449. 
Keith, K.D., Schalock, R.L. (1994). The Measurement of Quality of Life in Adolescence: The Quality of Student Life Questionnaire. The American Journal of Family Therapy, 22(1), 83-87, doi: 10.1080/01926189408251300.

Kizeweter, A. (2016). Szczęśliwy uczeń - szczęśliwy nauczyciel. Dobrostan szkolny wyzwaniem dla edukacji [Happy Student - Happy Teacher. School Welfare as a Challenge for Education]. In: J. Skibska, \& J. Wojciechowska (Eds.), Wspótczesna edukacja. Wielopłaszczyznowość zadań [Contemporary Education. Multidimensionality of Tasks] (pp. 27-36). Kraków: Wydawnictwo LIBRON.

Kristof, A.L. (1996). Person-Organization Fit: An Integrative Review of Its Conceptualizations, Measurements, and Implications. Personell Psychology, 49, 1-49, doi: 10.1111/ j.1744-6570.1996.tb01790.x.

Konu, A., Alanen, E., Lintonen, T., \& Rimpelä, M. (2002). Factor Structure of the School Well-Being Model. Health Education Research, 17(6), 732-742, doi: 10.1093/ her/17.6.732.

Konu, A., \& Lintonen, T. (2005). Theory-Based Survey Analysis of Well-Being in Secondary Schools in Finland. Health Promotion International, 21(1), 27-36, doi: 10.1093/ heapro/dai028.

Lyubomirsky, S., King, L., \& Diener, E. (2005). The Benefits of Frequent Positive Affect: Does Happiness Lead to Success? Psychological Bulletin, 131, 803-855, doi: 10.1037/0033-2909.131.6.803.

Nesse, R.M. (2020). Dobre powody złego samopoczucia. Odkrycia psychiatrii ewolucyjnej [Good Reasons for Bad Feelings. Insights from the Frontier of Evolutionary Psychiatry]. Warszawa: Wydawnictwo CeDeWu.

Nyczaj-Drąg, M. (2003). W poszukiwaniu teoretycznych podstaw badań nad samopoczuciem ucznia w szkole [In Search of Theoretical Foundations for Research on Student Well-Being at School]. Rocznik Lubuski, XXIX. In: K. Ferenz (Ed.), Dziecko w codzienności szkolnej [A Child in Everyday School Life] (pp. 65-74).

Opre, D., Pintea, S., Opre, A., \& Bertea, M. (2018). Measuring Adolescents' Subjective Well-Being in Educational Context: Development and Validation of a Multidimensional Instrument. Journal of Evidence-Based Psychotherapies, 18(2), 161-180, doi: 10.24193/ jebp.2018.2.20.

Petelewicz, M. (2016). Jakość życia dzieci a status społeczno-ekonomiczny rodziny. Teoria i badania. [The Quality of Life of Children and the Socio-Economic Status of the Family. Theory and Research]. Łódź: Wydawnictwo Uniwersytetu Łódzkiego.

Pollard, E.L., \& Lee, P.D. (2003). Child Well-Being: A Systematic Review of the Literature. Social Indicators Research, 61(1), 59-78, doi: 10.1023/A\%3A1021284215801. 
Renshaw, T.L., \& Arslan, G. (2016). Psychometric Properties of the Student Subjective Wellbeing Questionnaire with Turkish Adolescents. Canadian Journal of School Psychology, 31(2), 139-151, doi: 10.1177/0829573516634644.

Renshaw, T.L., Long, A.C.J., \& Cook, C.R. (2015). Assessing Adolescents' Positive Psychological Functioning At School: Development and Validation of the Student Subjective Wellbeing Questionnaire. School Psychology Quarterly, 30(4), 534-552.

Ryff, C.D., \& Keyes, C.L.M. (1995). The Structure of Psychological Well-Being Revisited. Journal of Personality and Social Psychology, 69(4), 719-727, doi: 10.1037/ spq0000088.

Rzeszutek, M., \& Schier, K. (2008). Tak bolesne, że aż obce? - związek pomiędzy depresją a obrazem ciała u młodych dorosłych. [So Painful that it's Alien? - the Relationship Between Depression and the Image Body in Young Adults]. Psychoterapia, 4(47), 5-16.

Salovey, P., Rothman, A.J., Detweiler, J.B., \& Steward, W.T. (2000). Emotional States and Physical Health. The American Psychologist Association, 1(55), 110-121, doi: 10.1037//0003-066X.55.1.110.

Soutter, A.K., O’Steen, B., \& Gilmore, A. (2013). The Student Well-Being Model: A Conceptual Framework for the Development of Student Well-Being Indicators. International Journal of Adolescence and Youth, 19(4), 496-520, doi: 10.1080/02673843.2012.754362.

Student Wellbeing (2018). Engagement and Learning Across the Middle Years the Centre for Adolescent Health is a Research Group of the Murdoch Children's Research Institute. Commonwealth of Australia.

Szyszko-Bohusz, A. (1989). Pedagogika holistyczna [Holistic Pedagogy]. Wrocław: Ossolineum.

Tian, L., Wang, D., \& Huebner, E.S. (2015). Development and Validation of the Brief Adolescents' Subjective Well-Being in School Scale (BASWBSS). Social Indicators Research, 120, 615-634, doi: 10.1007/s11205-014-0603-0.

Tomyn, A.J., \& Cummins, R.A. (2011). The Subjective Well-Being of High-School Students: Validating the Personal Well-Being Index - School Children. Social Indicators Research, 101, 405-418, doi: 10.1007/s11205-010-9668-6.

Tucholska, K., \& Gulla, B. (2007). Psychologia pozytywna - krytyczna analiza koncepcji. [Positive Psychology - Critical Concept Analysis]. Studia z Psychologii w KUL, 14, $107-131$.

Van Petegem, K., Aelterman, A., Rosseel, Y., \& Creemers, B. (2007). Student Perception as Moderator for Student Well-Being. Social Indicators Research, 83, 447-463, doi: 10.1007/s11205-006-9055-5.

WHO. Global School Health Initiative. Retrieved 10 July 2021 from: https:/www.who.int/ school_youth_health/gshi. 